\title{
Rare germline genetic variants and risk of aggressive prostate cancer
}

Tú Nguyen-Dumont ${ }^{1,2}$, Robert J. MacInnis ${ }^{3,4}$, Jason A. Steen ${ }^{1}$, Derrick Theys ${ }^{1}$, Helen Tsimiklis $^{1,2}$, Fleur Hammet ${ }^{1,2}$, Maryam Mahmoodi ${ }^{1,2}$, Bernard J. Pope ${ }^{1,5,6,7}$, Daniel J. Park ${ }^{2,7}$, Khalid Mahmood ${ }^{6,7}$, Gianluca Severi ${ }^{8,9}$, Damien Bolton ${ }^{10}$, Roger L. Milne ${ }^{1,3,4}$, Graham G. Giles $^{3,4}$, Melissa C. Southey ${ }^{1,2,3,5}$

${ }^{1}$ Precision Medicine, School of Clinical Sciences at Monash Health, Monash University, Clayton, Victoria, 3168, Australia

${ }^{2}$ Department of Clinical Pathology, The University of Melbourne, Victoria, 3010, Australia

${ }^{3}$ Cancer Epidemiology Division, Cancer Council Victoria, Victoria, 3004, Australia

${ }^{4}$ Centre for Epidemiology and Biostatistics, The University of Melbourne, Victoria, 3010, Australia

${ }^{5}$ The University of Melbourne Centre for Cancer Research, Victoria Comprehensive Cancer Centre, Victoria, 3010, Australia

${ }^{6}$ Colorectal Oncogenomics Group, Department of Clinical Pathology, The University of Melbourne, Victoria, 3010, Australia

${ }^{7}$ Melbourne Bioinformatics, The University of Melbourne, Victoria, 3010, Australia ${ }^{8}$ CESP Inserm U1018, Faculté de médecine - Univ. Paris-Sud, Faculté de médecine - UVSQ, Université Paris-Saclay, 94805, Villejuif, France

${ }^{9}$ Gustave Roussy, F-94805, Villejuif, France

This is the author manuscript accepted for publication and has undergone full peer review but has not been through the copyediting, typesetting, pagination and proofreading process, which may lead to differences between this version and the Version of Record. Please cite this article as doi: $10.1002 / \mathrm{ijc} 33024$

This article is protected by copyright. All rights reserved. 
${ }^{10}$ Department of Surgery, The University of Melbourne, Austin Health, Victoria, 3084, Australia

\title{
Corresponding author:
}

Prof Melissa C. Southey

Precision Medicine, School of Clinical Sciences at Monash Health, Monash University, Clayton, Victoria, 3168, Australia

Department of Clinical Pathology, The University of Melbourne, Victoria, 3010, Australia Cancer Epidemiology Division, Cancer Council Victoria, Victoria, 3004, Australia The University of Melbourne Centre for Cancer Research, Victoria Comprehensive Cancer Centre, Victoria, 3010, Australia

melissa.southey@monash.edu

Keywords: aggressive prostate cancer, gene panel testing, germline genetic variants

\begin{abstract}
Abbreviations: LoF: loss-of-function; MAF: minor allele frequency; mCRPC: metastatic castration-resistant PrCa; PARPi: PARP inhibitors; P/LP: pathogenic/likely pathogenic; PrCa: prostate cancer
\end{abstract}

\section{Novelty and Impact:}

Identifying which men at the time of prostate cancer diagnosis have, or will progress to, aggressive fatal disease remains an important clinical and public health issue. Germline gene

This article is protected by copyright. All rights reserved. 
panel testing offers opportunities for identifying men who carry BRCA2 pathogenic variants who are at increased risk of aggressive disease. Our case-case study confirms this and provides further supportive evidence that men with pathogenic variants in ATM are also at increased risk of aggressive disease. The clinical relevance of the genetic variation identified in most of the other genes included in these gene panel tests remains uncertain and requires international attention and collaboration.

\begin{abstract}
Few genetic risk factors have been demonstrated to be specifically associated with aggressive prostate cancer (PrCa). Here, we report a case-case study of PrCa comparing the prevalence of germline pathogenic/likely pathogenic (P/LP) genetic variants in 787 men with aggressive disease and 769 with non-aggressive disease.

Overall, we observed P/LP variants in $11.4 \%$ of men with aggressive PrCa and $9.8 \%$ of men with non-aggressive PrCa (two-tailed Fisher's exact tests, $\mathrm{P}=0.28$ ). The proportion of $B R C A 2$ and ATM P/LP variant carriers in men with aggressive PrCa exceeded that observed in men with non-aggressive PrCa; $18 / 787$ carriers (2.3\%) and 4/769 carriers (0.5\%), $\mathrm{P}=0.004$, and $14 / 787$ carriers $(0.02 \%)$ and $5 / 769$ carriers $(0.01 \%), \mathrm{P}=0.06$, respectively. Our findings contribute to the extensive international effort to interpret the genetic variation identified in genes included on gene-panel tests, for which there is currently an insufficient evidence-base for clinical translation in the context of PrCa risk.
\end{abstract}

This article is protected by copyright. All rights reserved. 


\section{Introduction}

A family history of prostate cancer ( $\mathrm{PrCa}$ ) is a well-established risk factor for developing the disease, indicating an important contribution of genetic risk factors in PrCa development. In a large twin study, Mucci et al. estimated that the heritability of prostate cancer was $57 \%$ [95\% $\mathrm{CI}=51-63 \%]$ and thus higher than that of breast $(31 \%[95 \% \mathrm{CI}=11-51 \%])$ and ovarian cancer (39\% $[95 \% \mathrm{CI}=23-55 \%])^{1}$. To date, more than 150 common genetic variants have been reported and account for approximately $28 \%$ of the familial risk of $\mathrm{PrCa}^{2-4}$. A rare missense variant in HOXB13 (c.251G>A; p.Gly84Glu) has been shown to be associated with increased risk of early-onset PrCa in the context of a family history of the disease ${ }^{5-8}$. This variant is estimated to account for $\sim 5 \%$ of familial aggregation of PrCa ${ }^{9}$. Family observations and candidate gene approaches have shown that pathogenic variants in some DNA repair genes are associated with an increased risk of PrCa. Edwards et al reported that 2\% of men diagnosed with PrCa under the age of 55 years carry pathogenic BRCA2 variants that are associated with an 8.6-fold increased PrCa risk by age 65 years ${ }^{10}$. Men who carry a germline pathogenic variant in BRCA1 are estimated to be at up to 4.5 -fold increased risk of PrCa ${ }^{11}$. PrCa cases who carry pathogenic variants in BRCA1 and BRCA2 (combined) are more commonly aggressive, have increased nodal involvement and metastases, and have poorer survival ${ }^{12-17}$. Most recently, the IMPACT study has conducted single gene analyses that demonstrated significant association between mutation carrier status and younger age at onset and clinically significant disease for men with BRCA2 pathogenic variants only ${ }^{18}$. PrCa arising in carriers of MLH1, MSH2, MSH6 and PMS2 germline pathogenic variants (Lynch syndrome) have been reported to be mismatch repair (MMR) deficient via immunohistochemistry ${ }^{19}$. Combined, men 
who carry a pathogenic variant in a MMR gene are reported to be at a 3.2-fold increased risk of PrCa, which has a notable contribution from variants in MSH2 (5.8-fold increased risk) ${ }^{19}$. A recent study of PMS2-associated Lynch syndrome found no association with prostate cancer risk $^{20}$.

By comparing men with and without PrCa using a case-control design, most studies to date have searched for inherited genetic variants that predispose men to overall PrCa risk. However, the identification of germline genetic factors that can predict not only risk, but the clinical outcome for PrCa, if diagnosed, can both improve early diagnosis of potentially aggressive and lethal cases, and reduce overtreatment of indolent disease. A limited number of publications have focused on inherited genetic variants that distinguish between risk for aggressive (metastatic) and non-aggressive (low clinical grade) PrCa using a case-case design ${ }^{4,21}$.

Here, we report a case-case study of PrCa comparing the prevalence of germline pathogenic genetic variants in men with aggressive and non-aggressive disease. Since most of the genes currently implicated in PrCa susceptibility are also at least putatively involved in predisposition to breast and/or ovarian cancer and Lynch syndrome, we designed a panel targeting the coding regions of ATM, BARD1, BRCA1, BRCA2, BRIP1, CDH1, CHEK2, FANCM, HOXB13, MLH1, MRE11A, MSH2, MSH6, MUTYH, NBN, NF1, PALB2, PTEN, RAD50, RAD51C, RAD51D, RECQL, RNASEL, STK11 and TP53, and selected regions of PMS2. We applied massively parallel sequencing to screen the coding regions and proximal intron-exon junctions of these 26 genes, in men with aggressive PrCa and men with non-aggressive disease. We focused the analysis on rare pathogenic/likely pathogenic (P/LP) variants and assessed the number of carriers of such variants for each gene, and across all genes.

This article is protected by copyright. All rights reserved. 


\section{Materials and Methods}

\section{Subjects}

Participants in this study were identified from i) the Melbourne Collaborative Cohort Study (MCCS), ii) the Aggressive Prostate Cancer (APC) study, iii) the Risk Factors for Prostate Cancer Study and iv) the Early-Onset Prostate Cancer Family Study 22-24.

Aggressive cases ( $n=787)$ were selected using the following criteria: PrCa as a cause of death (regardless of stage or Gleason score at diagnosis), or stage 4 (regardless of Gleason score) or stage 3 and Gleason score $>=8$. Non-aggressive cases $(n=770)$ were selected using the following criteria: stage 1 (T1/T2a) and Gleason score $<=6$ and age at diagnosis $>=65$ years; or stage $1(\mathrm{~T} 1 / \mathrm{T} 2 \mathrm{a})$ and Gleason score $<=6$ and age at diagnosis $55-64$ years and $>=10$ years of follow-up; or stage 2 and Gleason score $<=6$, age at diagnosis $>=65$ years and $>=10$ years of follow-up. Germline DNA from these 1,557 participants was obtained from blood samples.

\section{Gene-panel sequencing}

The following 26 genes were included in the panel: ATM (NM_000051.3), BARD1 (NM_000465.2), BRCA1 (NM_007294.3), BRCA2 (NM_000059.3), BRIP1 (NM_032043.2), CDH1 (NM_004360.3), CHEK2 (NM_007194.3), FANCM (NM_020937.2), HOXB13 (NM_006361.5), MLH1 (NM_000249.3), MRE11A (NM_005591.3), MSH2 (NM_000251.2), MSH6 (NM_000179.2), $\quad$ MUTYH $\quad$ (NM_001128425.1), NBN $\quad$ (NM_002485.4), $\quad$ NF1 (NM_000267.3), PALB2 (NM_024675.3), PMS2 (NM_000535.5), PTEN (NM_000314.4), RAD50 (NM_005732.3), RAD51C (NM_058216.2), RAD51D (NM_002878.3), RECQL (NM_002907.3), RNASEL (NM_021133.3), STK11 (NM_000455.4), TP53 (NM_000546.5).

This article is protected by copyright. All rights reserved. 
Amplicon-based sequencing of the coding regions and proximal intron-exon junctions of 26 genes was performed using the Hi-Plex2 protocol $^{25}$. For PMS2, panel design avoided regions of homology with the pseudo-gene PMS2CL. A BED file of the targeted regions is available as Supplementary Data. Massively parallel sequencing (150 bp paired-end) was performed on the NextSeq550 platform (v2 chemistry, 2x150 bp) (Illumina, San Diego, CA, USA).

Paired-end reads were aligned to the reference genome (GRCh37) using bwa-mem 0.7.17 ${ }^{26}$. Target coverage was then calculated using bedtools ${ }^{27}$. Samples with $\geq 80 \%$ target bases covered at $\geq 50 \mathrm{X}$ sequencing depth were considered successfully sequenced. Applying these criteria, 787/787 aggressive and 769/770 non-aggressive PrCa cases progressed to variant calling. Variants were called using the Java version of VarDict in single sample ampliconmode $^{28}$.

\section{Variant annotation and classification}

Variant calls were annotated using VEP and loaded into GEMINI, according to the authors recommendations ${ }^{29,30}$. Variant nomenclature followed recommendations from the Human Genome Variation Society and used the reference transcripts listed above. Further analysis was restricted to variants that had a read depth $\geq 50 \mathrm{X}$ and a variant allele frequency $\geq 0.2$, in the coding regions and within 20bp of the intron-exon boundaries of the genes included on the panel.

Rare variants were defined as variants reported by the Exome Aggregation Consortium (ExAC) with a minor allele frequency $(\mathrm{MAF}) \leq 0.02$ in the non-Finnish European population (NFEnon TCGA) ${ }^{31}$.

This article is protected by copyright. All rights reserved. 
Clinical interpretation was performed based on the American College of Medical Genetics and Genomics (ACMG) criteria and ClinVar (accessed 09/2019) ${ }^{32,33}$. This study focused on rare, pathogenic or predicted loss of function $(\mathrm{LoF})$ variants. All LoF variants (ie. nonsense, frameshifting indels and consensus splice site variants) were called pathogenic/likely pathogenic (P/LP) unless the LoF variant was classified as benign or likely benign in ClinVar (review status at least “2 stars”). Non-LoF variants were called P/LP when ClinVar assessment of pathogenicity and likely pathogenicity was " 2 stars” or more, with multiple submitters and no conflicts.

\section{Statistical analysis}

The difference in the proportion of pathogenic mutation carriers for each gene, and across all genes, in the aggressive and non-aggressive PrCa cases was assessed using two-tailed Fisher's exact tests. No adjustment was made for multiple comparison.

\section{Results}

We assessed 26 genes involved in DNA repair and autosomal dominant cancer-predisposition syndromes in 787 aggressive PrCa and 770 non-aggressive cases. The clinical characteristics of the study participants are summarized in Table 1. Genetic testing was successfully performed for 787/787 (100\%) participants with aggressive PrCa and 769/770 (99.9\%) participants with non-aggressive PrCa. The median coverage per sample was 650X and 94.5\% samples had $\geq 90 \%$ of the target bases covered at least at $50 \mathrm{X}$.

This article is protected by copyright. All rights reserved. 
We identified a total of 95 P/LP variants in 90/787 (11.4\%) men with aggressive PrCa and 82 $\mathrm{P} / \mathrm{LP}$ variants in 75/769 (9.8\%) men with non-aggressive PrCa ( $\mathrm{P}=0.28$, Table 2, Figure 1$)$. All observed P/LP variants are reported in Supplementary Table 1.

Consistent with the literature, we found that HOXB13:c.251G>A; p.Gly84Glu was not associated with disease aggressiveness (10 non-aggressive PrCa cases, 8 aggressive $\operatorname{PrCa}$ cases, $\mathrm{P}=0.81$ ). Our results support the established association of BRCA2 $\mathrm{P} / \mathrm{LP}$ variants with increased risk of aggressive disease. The proportion of BRCA2 P/LP variant carriers in the aggressive PrCa group (2.3\%, 18/787 men) exceeded that observed in the non-aggressive PrCa group $(0.5 \%, 4 / 769$ men) $(\mathrm{P}=0.004)$ (Table 2, Figure 1). There were 23 distinct BRCA2 variants, 20 of which had expert panel-classification of Pathogenic in ClinVar. Two of the remaining BRCA2 variants had a "2 stars"-classification as Pathogenic in ClinVar: BRCA2:c.631G>A and c.9117G>A. These variants have been shown to cause aberrant splicing that leads to skipping of exon 7 and exon 23 of the BRCA2 mRNA, respectively ${ }^{34-39}$. BRCA2: c.8816delA has not yet received a ClinVar classification.

Other genes in which the proportion of P/LP variant carriers was higher in the aggressive PrCa group included ATM (14 (1.8\%) men with aggressive PrCa versus five (0.7\%) men with nonaggressive PrCa, respectively, $\mathrm{P}=0.06)$, CHEK2 (10 (1.3\%) men versus 5 (0.7\%) men, respectively, $\mathrm{P}=0.30)$, and $B R C A 1$ (5 (0.7\%) men versus 2 (0.3\%) men, respectively, $\mathrm{P}=0.45)$ (Table 2, Figure 1).

Apart from BRCA2, the genes with the highest number of rare P/LP variants overall in both groups were MUTYH (n=29), HOXB13 (n=19), RNASEL (n=18) (Table 2, Figure 1). Genetic variants in MUTYH and RNASEL were less prevalent in men who had aggressive PrCa 
compared with men who had non-aggressive disease ( $\mathrm{P}=0.27$ and $\mathrm{P}=0.16$, respectively) (Table 2, Figure 1). We observed one nonsense variant (HOXB13:c.327C $>\mathrm{G})$ in a man with aggressive PrCa. Thirteen of the 18 carriers of P/LP variants in RNASEL carried RNASEL: c.793G>T, a nonsense variant, classified as pathogenic for PrCa susceptibility in ClinVar.

For five genes, P/LP genetic variants were observed only in men with non-aggressive PrCa but none of these results were statistically significant: $B R I P 1$ (one carrier, $\mathrm{P}=0.50$ ), $M R E 11 A, N F 1$ (two carriers each, $\mathrm{P}=0.25$ ), $R A D 50$ and $R A D 51 C$ (three carriers each, $\mathrm{P}=0.12$ ) (Table 2).

We observed a total of 11 men with two or more distinct P/LP variants. In the aggressive PrCa group, four carried P/LP variants in two different genes (BRCA2:c.3778_3779delTT and MUTYH:c.536A>G; CHEK2:c.1100delC and FANCM:c.5101C>T; ATM:c.709dupA and HOXB13:c.327G>C; and BRCA2:c.6486_6489del and RECQL:c.1859C>G), and one man carried two pathogenic variants in BRCA2 (BRCA2:c.631G>A and c.7008-2A > T). These two variants have been shown to be in cis $^{34,35}$.

In the non-aggressive group, there were six men with two or more P/LP variants each; four carried P/LP variants in two distinct genes (ATM:c.8786+1G $>\mathrm{A}$ and RAD51C:c.1057_1066delCTGCATGTT; MRE11A:c.1927-2A>G and RAD51C:c.773G>A; MUTYH:c.536A >G and RNASEL:c.793G>T; MUTYH:c.536A $>\mathrm{G}$ and RECQL:c.1859C>G) and one man carried two BRCA2 variants (BRCA2:c.3405C>A and c.8673_8674delAA). One man carried three P/LP variants (CHEK2:c.655delG, NF1:c.2033dupC and NF1:c.2186_2190_dupATAAC).

\section{Discussion}

This article is protected by copyright. All rights reserved. 
One of the major clinical challenges of PrCa is the clinical heterogeneity in the disease. Identifying genetic risk factors for disease aggressiveness may enable distinct clinical management strategies for men at high or low risk of developing this subtype, and thus, the development of a personalized approach to PrCa management. Men with such P/LP variants are not likely to be good candidates for management via active surveillance protocols, and conversely men without such variants may be able to be more confidently managed in such a fashion.

In a recent study involving 201 men with aggressive PrCa and 1,048 men with non-aggressive PrCa, Leongamornlert et al. presented evidence for P/LP variants in BRCA2 to be associated with increased risk of aggressive PrCa ${ }^{40}$. The authors also found that carriers of P/LP variants in MSH2 and CHEK2 were at increased risk of developing aggressive disease. We observed too few P/LP MSH2 variants to test the MSH2 association with rigour (one carrier with aggressive PrCa and two carriers with non-aggressive disease). For CHEK2, their study found that only non-1100delC variants were associated with aggressive PrCa. We identified nine carriers of 1100delC in the aggressive group and three in the non-aggressive group. Although the findings were non-significant $(1.1 \%$ and $0.4 \%, \mathrm{P}=0.14)$, they are consistent with those from Wu et al. who reported a higher proportion of CHEK2 c.1100delC carriers in men with lethal PrCa (1.28\%) compared to those with low-risk disease (0.16\%), $\mathrm{P}=0.003 .{ }^{41}$. Surprisingly, Leongamornlert et al. identified ATM P/LP variants only in the non-aggressive PrCa cases (seven carriers, 0.67\%). Our study identified more men with a P/LP variant in ATM in the aggressive PrCa group than in the non-aggressive PrCa group $(\mathrm{P}=0.06)$. ATM:c.7271T $>\mathrm{G}$, for which there is overwhelming evidence supporting an association with breast cancer risk similar 
in magnitude to BRCA2 pathogenic variants, was identified twice in this study- both times in men with aggressive $\operatorname{PrCa}{ }^{42,43}$.

In the field of hereditary breast and ovarian cancer, carriers of BRCA1 and BRCA2 pathogenic variants are known to be responsive to PARP inhibitors (PARPi), as well as platinum-based chemotherapy. The TOPARP study, a phase II trial evaluating men affected with PrCa treated with the PARPi olaparib, found that of the 16/49 study participants who responded to olaparib, six carried a germline pathogenic variant in a DNA repair gene (three in BRCA2 and three in $A T M)^{44}$. The other eight carried somatic variants in BRCA1, CHEK2, PALB2, FANCA and HDAC2. However, recently Marshall et al. have reported the outcome of a systematic review of 23 consecutive men with metastatic castration-resistant PrCa (mCRPC) carrying pathogenic germline and/or somatic variants in BRCA1, BRCA2 or ATM treated with olaparib at three academic sites in the USA ${ }^{45}$. PSA responses to olaparib were achieved in 76\% (13/17) of men with BRCA1 or BRCA2 compared to $0 \%(0 / 6)$ of men with ATM pathogenic variants who also had significantly shorter progression-free survival. Consistent with this observation, recent work applying CRISPR/Cas9 editing has provided evidence that ATM pathogenic variants can contribute to mCRPC progression via metabolic rather than DNA repair mechanisms ${ }^{46}$. The rarity of P/LP variants continues to challenge translational research as illustrated by Castro et al. who conducted a study in 419 men with mCRPC to evaluate the effect of pathogenic variants in DNA damage repair genes on response to taxane therapy ${ }^{47}$. Of these men, only 26 carried a germline pathogenic variant in BRCA1, BRCA2 or ATM. Despite the study not reaching its primary end point, cause-specific survival was halved in BRCA2 pathogenic

This article is protected by copyright. All rights reserved. 
variant carriers, suggesting that genetic testing of men with mCRPC may inform the selection of initial treatment.

Table 2 and Figure 1 illustrate the volume of genetic variation that is identified when using gene panel tests and that the data generated for the majority of genes included in these tests is currently uninterpretable. Interpretation of the genetic variation in genes such as BRCA1, BRCA2, HOXB13 and ATM, for which data has been accumulating for some time, is more advanced but a considerable proportion of the variants remain of uncertain significance ${ }^{18,48}$, 49.

Although variants that can be classified as P/LP are rare, when considered in the context of commercial multigene testing for prostate cancer susceptibility, it is clear that the number of men to whom this information could be clinically relevant is not inconsequential. For example, Giri et al. report that $11 \%$ of men undergoing multigene testing for prostate cancer susceptibility (unselected for metastatic disease) had pathogenic variants in DNA repair genes that have implications for therapeutic management and cascade testing ${ }^{50}$.

Recognised gaps in knowledge currently include cost-effectiveness of genetic testing for PrCa susceptibility and whether the strategies for testing should include breast cancer family history information and/or Gleason score ${ }^{50}$.

Further extensive internationally coordinated studies are required to confidently classify rare pathogenic variants identified in multigene-testing. Evidence is accumulating in relation to the use of genetic information about $A T M$ in the clinical management of men with prostate cancer. Much more data is required to interpret variation in CHEK2 (observed in 1-2.2\% of affected

This article is protected by copyright. All rights reserved. 
men (this report and ${ }^{50}$ ) and the many other genes currently included on commercial multi-gene testing panels for which there is currently an insufficient evidence-base for clinical translation.

\section{Acknowledgements}

We thank Drs Pierre-Antoine Dugué and Anne-Laure Renault for their comments on the manuscript.

Conflict of interest disclosure: The authors have no conflict of interest to disclose.

Data accessibility: data is available upon reasonable request.

Ethical approval and informed consent: The participants to the APC study, EOPCFS, MCCS and RFPCFS provided informed consent. This study was approved by the Cancer Council Victoria Human Research Ethics Committee and the Monash University Research Ethics Committee.

Funding: TN-D a National Breast Cancer Foundation (Australia) Career Development Fellow (ECF-17-001). BJP is the recipient of a Victorian Health and Medical Research Fellowship. MCS is a National Health and Medical Research Council (NMHRC, Australia) Senior Research Fellow (APP1155163). This work was supported by an NHMRC Program grant (APP1074383).

\section{References}

1. Mucci LA, Hjelmborg JB, Harris JR, Czene K, Havelick DJ, Scheike T, Graff RE, Holst K, Moller S, Unger RH, McIntosh C, Nuttall E, et al. Familial Risk and Heritability of Cancer Among Twins in Nordic Countries. JAMA 2016;315:68-76.

This article is protected by copyright. All rights reserved. 
2. Teerlink CC, Thibodeau SN, McDonnell SK, Schaid DJ, Rinckleb A, Maier C, Vogel W, Cancel-Tassin G, Egrot C, Cussenot O, Foulkes WD, Giles GG, et al. Association analysis of 9,560 prostate cancer cases from the International Consortium of Prostate Cancer Genetics confirms the role of reported prostate cancer associated SNPs for familial disease. Hum Genet 2014;133:347-56.

3. Eeles RA, Al Olama AA, Benlloch S, Saunders EJ, Leongamornlert DA, Tymrakiewicz M, Ghoussaini M, Luccarini C, Dennis J, Jugurnauth-Little S, Dadaev T, Neal DE, et al. Identification of 23 new prostate cancer susceptibility loci using the iCOGS custom genotyping array. Nature Genetics 2013;45:385-91.

4. Schumacher FR, Al Olama AA, Berndt SI, Benlloch S, Ahmed M, Saunders EJ, Dadaev T, Leongamornlert D, Anokian E, Cieza-Borrella C, Goh C, Brook MN, et al. Association analyses of more than 140,000 men identify 63 new prostate cancer susceptibility loci. Nat Genet 2018;50:928-36.

5. Ewing CM, Ray AM, Lange EM, Zuhlke KA, Robbins CM, Tembe WD, Wiley KE, Isaacs SD, Johng D, Wang Y, Bizon C, Yan G, et al. Germline mutations in HOXB13 and prostate-cancer risk. N Engl J Med 2012;366:141-9.

6. Breyer JP, Avritt TG, McReynolds KM, Dupont WD, Smith JR. Confirmation of the HOXB13 G84E germline mutation in familial prostate cancer. Cancer Epidemiol Biomarkers Prev 2012;21:1348-53.

7. MacInnis RJ, Severi G, Baglietto L, Dowty JG, Jenkins MA, Southey MC, Hopper JL, Giles GG. Population-based estimate of prostate cancer risk for carriers of the HOXB13 missense mutation G84E. PLoS One 2013;8:e54727.

This article is protected by copyright. All rights reserved. 
8. Figlioli G, Bogliolo M, Catucci I, Caleca L, Lasheras SV, Pujol R, Kiiski JI, Muranen TA, Barnes DR, Dennis J, Michailidou K, Bolla MK, et al. The FANCM:p.Arg658* truncating variant is associated with risk of triple-negative breast cancer. NPJ Breast Cancer 2019;5:38.

9. Xu J, Lange EM, Lu L, Zheng SL, Wang Z, Thibodeau SN, Cannon-Albright LA, Teerlink CC, Camp NJ, Johnson AM, Zuhlke KA, Stanford JL, et al. HOXB13 is a susceptibility gene for prostate cancer: results from the International Consortium for Prostate Cancer Genetics (ICPCG). Hum Genet 2013;132:5-14.

10. Edwards SM, Kote-Jarai Z, Meitz J, Hamoudi R, Hope Q, Osin P, Jackson R, Southgate C, Singh R, Falconer A, Dearnaley DP, Ardern-Jones A, et al. Two percent of men with early-onset prostate cancer harbor germline mutations in the BRCA2 gene. Am J Hum Genet 2003;72:1-12.

11. Leongamornlert D, Mahmud N, Tymrakiewicz M, Saunders E, Dadaev T, Castro E, Goh C, Govindasami K, Guy M, O'Brien L, Sawyer E, Hall A, et al. Germline BRCA1 mutations increase prostate cancer risk. Br J Cancer 2012;106:1697-701.

12. Tryggvadottir L, Vidarsdottir L, Thorgeirsson T, Jonasson JG, Olafsdottir EJ, Olafsdottir GH, Rafnar T, Thorlacius S, Jonsson E, Eyfjord JE, Tulinius H. Prostate cancer progression and survival in BRCA2 mutation carriers. J Natl Cancer Inst 2007;99:929-35.

13. Narod SA, Neuhausen S, Vichodez G, Armel S, Lynch HT, Ghadirian P, Cummings S, Olopade O, Stoppa-Lyonnet D, Couch F, Wagner T, Warner E, et al. Rapid progression of prostate cancer in men with a BRCA2 mutation. Br J Cancer 2008;99:371-4.

This article is protected by copyright. All rights reserved. 
14. Gallagher DJ, Gaudet MM, Pal P, Kirchhoff T, Balistreri L, Vora K, Bhatia J, Stadler Z, Fine SW, Reuter V, Zelefsky M, Morris MJ, et al. Germline BRCA mutations denote a clinicopathologic subset of prostate cancer. Clin Cancer Res 2010;16:2115-21.

15. Kote-Jarai Z, Leongamornlert D, Saunders E, Tymrakiewicz M, Castro E, Mahmud N, Guy M, Edwards S, O'Brien L, Sawyer E, Hall A, Wilkinson R, et al. BRCA2 is a moderate penetrance gene contributing to young-onset prostate cancer: implications for genetic testing in prostate cancer patients. Br J Cancer 2011;105:1230-4.

16. Castro E, Goh C, Leongamornlert D, Saunders E, Tymrakiewicz M, Dadaev T, Govindasami K, Guy M, Ellis S, Frost D, Bancroft E, Cole T, et al. Effect of BRCA Mutations on Metastatic Relapse and Cause-specific Survival After Radical Treatment for Localised Prostate Cancer. Eur Urol 2015;68:186-93.

17. Dias A, Kote-Jarai Z, Mikropoulos C, Eeles R. Prostate Cancer Germline Variations and Implications for Screening and Treatment. Cold Spring Harb Perspect Med 2018;8.

18. Page EC, Bancroft EK, Brook MN, Assel M, Al Battat MH, Thomas S, Taylor N, Chamberlain A, Pope J, Ni Raghallaigh H, Evans DG, Rothwell J, et al. Interim Results from the IMPACT Study: Evidence for Prostate-specific Antigen Screening in BRCA2 Mutation Carriers. European Urology 2019;76:831-42.

19. Rosty C, Walsh MD, Lindor NM, Thibodeau SN, Mundt E, Gallinger S, Aronson M, Pollett A, Baron JA, Pearson S, Clendenning M, Walters RJ, et al. High prevalence of mismatch repair deficiency in prostate cancers diagnosed in mismatch repair gene mutation carriers from the colon cancer family registry. Fam Cancer 2014;13:573-82.

This article is protected by copyright. All rights reserved. 
20. Ten Broeke SW, van der Klift HM, Tops CMJ, Aretz S, Bernstein I, Buchanan DD, de la Chapelle A, Capella G, Clendenning M, Engel C, Gallinger S, Gomez Garcia E, et al. Cancer Risks for PMS2-Associated Lynch Syndrome. J Clin Oncol 2018;36:2961-68.

21. Xu JF, Zheng SL, Isaacs SD, Wiley KE, Wiklund F, Sun JL, Kader AK, Li G, Purcell LD, Kim ST, Hsu FC, Stattin P, et al. Inherited genetic variant predisposes to aggressive but not indolent prostate cancer. P Natl Acad Sci USA 2010;107:2136-40.

22. Milne RL, Fletcher AS, MacInnis RJ, Hodge AM, Hopkins AH, Bassett JK, Bruinsma FJ, Lynch BM, Dugue PA, Jayasekara H, Brinkman MT, Popowski LV, et al. Cohort Profile: The Melbourne Collaborative Cohort Study (Health 2020). Int J Epidemiol 2017;46:1757-57i.

23. Papa NP, MacInnis RJ, English DR, Bolton D, Davis ID, Lawrentschuk N, Millar JL, Pedersen J, Severi G, Southey MC, Hopper JL, Giles GG. Ejaculatory frequency and the risk of aggressive prostate cancer: Findings from a case-control study. Urol Oncol 2017;35:530 e7-30 e13.

24. Giles GG, Severi G, Sinclair R, English DR, McCredie MR, Johnson W, Boyle P, Hopper JL. Androgenetic alopecia and prostate cancer: findings from an Australian casecontrol study. Cancer Epidemiol Biomarkers Prev 2002;11:549-53.

25. Hammet F, Mahmood K, Green TR, Nguyen-Dumont T, Southey MC, Buchanan DD, Lonie A, Nathanson KL, Couch FJ, Pope BJ, Park DJ. Hi-Plex2: a simple and robust approach to targeted sequencing-based genetic screening. Biotechniques 2019.

26. Li H, Durbin R. Fast and accurate short read alignment with Burrows-Wheeler transform. Bioinformatics 2009;25:1754-60.

This article is protected by copyright. All rights reserved. 
27. Quinlan AR, Hall IM. BEDTools: a flexible suite of utilities for comparing genomic features. Bioinformatics 2010;26:841-2.

28. Lai Z, Markovets A, Ahdesmaki M, Chapman B, Hofmann O, McEwen R, Johnson J, Dougherty B, Barrett JC, Dry JR. VarDict: a novel and versatile variant caller for nextgeneration sequencing in cancer research. Nucleic Acids Res 2016;44:e108.

29. McLaren W, Gil L, Hunt SE, Riat HS, Ritchie GR, Thormann A, Flicek P, Cunningham F. The Ensembl Variant Effect Predictor. Genome Biol 2016;17:122.

30. Paila U, Chapman BA, Kirchner R, Quinlan AR. GEMINI: integrative exploration of genetic variation and genome annotations. PLoS Comput Biol 2013;9:e1003153.

31. Lek M, Karczewski KJ, Minikel EV, Samocha KE, Banks E, Fennell T, O'DonnellLuria AH, Ware JS, Hill AJ, Cummings BB, Tukiainen T, Birnbaum DP, et al. Analysis of protein-coding genetic variation in 60,706 humans. Nature 2016;536:285-91.

32. Richards S, Aziz N, Bale S, Bick D, Das S, Gastier-Foster J, Grody WW, Hegde M, Lyon E, Spector E, Voelkerding K, Rehm HL, et al. Standards and guidelines for the interpretation of sequence variants: a joint consensus recommendation of the American College of Medical Genetics and Genomics and the Association for Molecular Pathology. Genet Med 2015;17:405-24.

33. Landrum MJ, Lee JM, Riley GR, Jang W, Rubinstein WS, Church DM, Maglott DR. ClinVar: public archive of relationships among sequence variation and human phenotype. Nucleic Acids Research 2014;42:D980-5.

This article is protected by copyright. All rights reserved. 
34. Pensabene M, Spagnoletti I, Capuano I, Condello C, Pepe S, Contegiacomo A, Lombardi G, Bevilacqua G, Caligo MA. Two mutations of BRCA2 gene at exon and splicing site in a woman who underwent oncogenetic counseling. Ann Oncol 2009;20:874-8.

35. Colombo M, Ripamonti CB, Pensotti V, Foglia C, Peissel B, Pierotti MA, Manoukian S, Radice P. An unusual BRCA2 allele carrying two splice site mutations. Ann Oncol 2009;20:1143-4.

36. Acedo A, Sanz DJ, Duran M, Infante M, Perez-Cabornero L, Miner C, Velasco EA. Comprehensive splicing functional analysis of DNA variants of the BRCA2 gene by hybrid minigenes. Breast Cancer Res 2012;14:R87.

37. Colombo M, De Vecchi G, Caleca L, Foglia C, Ripamonti CB, Ficarazzi F, Barile M, Varesco L, Peissel B, Manoukian S, Radice P. Comparative in vitro and in silico analyses of variants in splicing regions of BRCA1 and BRCA2 genes and characterization of novel pathogenic mutations. PLoS One 2013;8:e57173.

38. Houdayer C, Caux-Moncoutier V, Krieger S, Barrois M, Bonnet F, Bourdon V, Bronner M, Buisson M, Coulet F, Gaildrat P, Lefol C, Leone M, et al. Guidelines for splicing analysis in molecular diagnosis derived from a set of 327 combined in silico/in vitro studies on BRCA1 and BRCA2 variants. Hum Mutat 2012;33:1228-38.

39. Acedo A, Hernandez-Moro C, Curiel-Garcia A, Diez-Gomez B, Velasco EA. Functional classification of BRCA2 DNA variants by splicing assays in a large minigene with 9 exons. Hum Mutat 2015;36:210-21.

40. Leongamornlert DA, Saunders EJ, Wakerell S, Whitmore I, Dadaev T, CiezaBorrella C, Benafif S, Brook MN, Donovan JL, Hamdy FC, Neal DE, Muir K, et al. Germline

This article is protected by copyright. All rights reserved. 
DNA Repair Gene Mutations in Young-onset Prostate Cancer Cases in the UK: Evidence for a More Extensive Genetic Panel. Eur Urol 2019;76:329-37.

41. Wu YS, Yu HJ, Zheng SL, Na R, Mamawala M, Landis T, Wiley K, Petkewicz J, Shah S, Shi ZQ, Novakovic K, McGuire M, et al. A comprehensive evaluation of CHEK2 germline mutations in men with prostate cancer. Prostate 2018;78:607-15.

42. Chenevix-Trench G, Spurdle AB, Gatei M, Kelly H, Marsh A, Chen X, Donn K, Cummings M, Nyholt D, Jenkins MA, Scott C, Pupo GM, et al. Dominant negative ATM mutations in breast cancer families. J Natl Cancer I 2002;94:205-15.

43. Southey MC, Goldgar DE, Winqvist R, Pylkas K, Couch F, Tischkowitz M, Foulkes WD, Dennis J, Michailidou K, van Rensburg EJ, Heikkinen T, Nevanlinna H, et al. PALB2, CHEK2 and ATM rare variants and cancer risk: data from COGS. Journal of Medical Genetics 2016.

44. Mateo J, Carreira S, Sandhu S, Miranda S, Mossop H, Perez-Lopez R, Nava Rodrigues D, Robinson D, Omlin A, Tunariu N, Boysen G, Porta N, et al. DNA-Repair Defects and Olaparib in Metastatic Prostate Cancer. N Engl J Med 2015;373:1697-708.

45. Marshall CH, Sokolova AO, McNatty AL, Cheng HH, Eisenberger MA, Bryce AH, Schweizer MT, Antonarakis ES. Differential Response to Olaparib Treatment Among Men with Metastatic Castration-resistant Prostate Cancer Harboring BRCA1 or BRCA2 Versus ATM Mutations. Eur Urol 2019.

46. Xu L, Ma E, Zeng T, Zhao R, Tao Y, Chen X, Groth J, Liang C, Hu H, Huang J. ATM deficiency promotes progression of CRPC by enhancing Warburg effect. Endocr Relat Cancer 2019;26:59-71.

This article is protected by copyright. All rights reserved. 
47. Castro E, Romero-Laorden N, Del Pozo A, Lozano R, Medina A, Puente J, Piulats JM, Lorente D, Saez MI, Morales-Barrera R, Gonzalez-Billalabeitia E, Cendon Y, et al. PROREPAIR-B: A Prospective Cohort Study of the Impact of Germline DNA Repair Mutations on the Outcomes of Patients With Metastatic Castration-Resistant Prostate Cancer. J Clin Oncol 2019;37:490-503.

48. Isaacs $\mathrm{WB}$, Cooney KA, Xu J. Updated insights into genetic contribution to prostate cancer predisposition: focus on HOXB13. Can J Urol 2019;26:12-13.

49. Momozawa Y, Iwasaki Y, Hirata M, Liu X, Kamatani Y, Takahashi A, Sugano K, Yoshida T, Murakami Y, Matsuda K, Nakagawa H, Spurdle AB, et al. Germline pathogenic variants in 7,636 Japanese patients with prostate cancer and 12,366 controls. J Natl Cancer Inst 2019.

50. Giri VN, Hegarty SE, Hyatt C, O'Leary E, Garcia J, Knudsen KE, Kelly WK, Gomella LG. Germline genetic testing for inherited prostate cancer in practice: Implications for genetic testing, precision therapy, and cascade testing. Prostate 2019;79:333-39.

This article is protected by copyright. All rights reserved. 
Table 1: Clinical characteristics of the participants to this study.

\begin{tabular}{|c|c|c|c|c|}
\hline \multirow{2}{*}{ Study } & \multicolumn{2}{|c|}{ Aggressive PrCa cases } & \multicolumn{2}{|c|}{ Non-aggressive PrCa cases } \\
\hline & $\mathbf{N}$ & $\%$ & $\mathbf{N}$ & $\%$ \\
\hline APC $^{\mathbf{a}}$ & 257 & $32.7 \%$ & 24 & $3.1 \%$ \\
\hline EOPCFS $^{a}$ & 185 & $23.5 \%$ & 99 & $12.9 \%$ \\
\hline MCCS $^{a}$ & 166 & $21.1 \%$ & 442 & $57.5 \%$ \\
\hline RFPCS $^{\mathbf{a}}$ & 179 & $22.7 \%$ & 204 & $26.5 \%$ \\
\hline \multicolumn{5}{|c|}{ Age at diagnosis (years) } \\
\hline$<60$ & 250 & $31.8 \%$ & 97 & $12.6 \%$ \\
\hline $60-64$ & 137 & $17.4 \%$ & 92 & $12.0 \%$ \\
\hline 65-69 & 235 & $29.9 \%$ & 298 & $38.8 \%$ \\
\hline$\geq 70$ & 165 & $21.0 \%$ & 282 & $36.7 \%$ \\
\hline \multicolumn{5}{|c|}{ Size of the primary tumour (T stage) } \\
\hline T1 & 290 & $36.8 \%$ & 666 & $86.6 \%$ \\
\hline $\mathbf{T 2}$ & 18 & $2.3 \%$ & 103 & $13.4 \%$ \\
\hline T3 & 341 & $43.3 \%$ & 0 & $0.0 \%$ \\
\hline T4 & 31 & $3.9 \%$ & 0 & $0.0 \%$ \\
\hline Unknown & 107 & $13.6 \%$ & 0 & $0.0 \%$ \\
\hline \multicolumn{5}{|c|}{ Spread to lymph nodes (N stage) } \\
\hline No & 743 & $94.4 \%$ & 769 & $100.0 \%$ \\
\hline Yes & 44 & $5.6 \%$ & 0 & $0.0 \%$ \\
\hline \multicolumn{5}{|c|}{ Presence of metastasis (M Stage) } \\
\hline No & 751 & $95.4 \%$ & 769 & $100.0 \%$ \\
\hline Yes & 36 & $4.6 \%$ & 0 & $0.0 \%$ \\
\hline \multicolumn{5}{|l|}{ Gleason score } \\
\hline 2 & 2 & $0.3 \%$ & 20 & $2.6 \%$ \\
\hline 3 & 1 & $0.1 \%$ & 24 & $3.1 \%$ \\
\hline 4 & 5 & $0.6 \%$ & 98 & $12.7 \%$ \\
\hline 5 & 16 & $2.0 \%$ & 126 & $16.4 \%$ \\
\hline 6 & 47 & $6.0 \%$ & 501 & $65.1 \%$ \\
\hline 7 & 132 & $16.8 \%$ & 0 & $0.0 \%$ \\
\hline 8 & 198 & $25.2 \%$ & 0 & $0.0 \%$ \\
\hline
\end{tabular}

This article is protected by copyright. All rights reserved. 


\begin{tabular}{|c|c|c|c|c|}
\hline $\mathbf{9}$ & 238 & $30.2 \%$ & 0 & $0.0 \%$ \\
\hline $\mathbf{1 0}$ & 25 & $3.2 \%$ & 0 & $0.0 \%$ \\
\hline Unknown & 123 & $15.6 \%$ & 0 & $0.0 \%$ \\
\hline \multicolumn{5}{|l|}{} \\
\hline Died with prostate cancer as the cause of death \\
\hline Yes & 468 & $59.5 \%$ & 0 & $0.0 \%$ \\
\hline No & 319 & $40.5 \%$ & 769 & $100.0 \%$ \\
\hline Total & $\mathbf{7 8 7}$ & & & \\
\hline
\end{tabular}

a APC, Aggressive Prostate Cancer study; EOPCFS, Early-Onset Prostate Cancer Family Study; MCCS, the Melbourne Collaborative Cohort Study; RFPCFS, Risk Factors for Prostate Cancer Study

${ }^{\mathrm{b}}$ All men with unknown T stage died of prostate cancer

This article is protected by copyright. All rights reserved. 
Table 2: Number of carriers of rare pathogenic/likely pathogenic variants observed per gene, in the aggressive (n=787 men) and non-aggressive (n=769 men) PrCa groups. In the aggressive PrCa group, five men each carried two distinct P/LP variants. In the non-aggressive PrCa group, there were five men who carried two P/LP variants each, and one man who carried three P/LP variants.

\begin{tabular}{|c|c|c|c|}
\hline Gene & $\begin{array}{l}\text { Aggressive } \\
\text { PrCa cases }^{\mathrm{a}}\end{array}$ & $\begin{array}{l}\text { Non-aggressive } \\
\text { PrCa cases }\end{array}$ & p-value ${ }^{b}$ \\
\hline ATM & 14 & 5 & 0.06 \\
\hline BARD1 & 1 & 1 & 1.00 \\
\hline BRCA1 & 5 & 2 & 0.45 \\
\hline BRCA2 & $18^{\mathrm{c}}$ & $4^{c}$ & $<0.01$ \\
\hline BRIP1 & 0 & 1 & 0.49 \\
\hline CDH1 & 0 & 0 & - \\
\hline CHEK2 & 10 & 5 & 0.30 \\
\hline FANCM & 4 & 3 & 1.00 \\
\hline HOXB13 & 11 & 8 & 0.65 \\
\hline MLH1 & 0 & 0 & - \\
\hline MRE11A & 0 & 2 & 0.24 \\
\hline MSH2 & 1 & 2 & 0.62 \\
\hline MSH6 & 3 & 1 & 0.62 \\
\hline MUTYH & 12 & 17 & 0.35 \\
\hline
\end{tabular}

This article is protected by copyright. All rights reserved. 


\begin{tabular}{|c|c|c|c|} 
NBN & 1 & 3 & 0.37 \\
\hline NF1 & 0 & $1^{\mathrm{c}}$ & 0.49 \\
\hline PALB2 & 3 & 1 & 0.62 \\
\hline PMS2 & 1 & 0 & 1.00 \\
\hline PTEN & 0 & 0 & - \\
\hline RAD50 & 0 & 3 & 0.12 \\
\hline RAD51C & 0 & 3 & 0.12 \\
\hline RAD51D & 1 & 1 & 1.00 \\
\hline RECQL & 3 & 5 & 0.50 \\
\hline RNASEL & 6 & 12 & 0.16 \\
\hline STK11 & 0 & 0 & - \\
\hline TP53 & 0 & 0 & - \\
\hline
\end{tabular}

${ }^{\text {a }}$ Carriers of P/LP: pathogenic or likely pathogenic variants: rare loss-of-function variants (excluding those predicted to be benign in ClinVar), and rare non-loss-of-function variants that have a "2-star” classification as “pathogenic” in ClinVar (accessed September 2019). One man in each group carried two BRCA2 P/LP variants. One man in the non-aggressive PrCa group carried two P/LP in NF1.

b Two-tailed Fisher's exact test

${ }^{\mathrm{c}}$ One man was found to carry two P/LP variants in this gene.

This article is protected by copyright. All rights reserved. 
Figure 1: Pie charts representing the proportion of carriers of a pathogenic/likely pathogenic (P/LP) genetic variant identified in the 26 gene-panel in $A)$ the aggressive PrCa (n=787 men) and B) the non-aggressive PrCa (n=769 men) groups. The bar plots represent the number of P/LP variants observed per gene in each group. * denotes genes in which no P/LP variant was identified.

This article is protected by copyright. All rights reserved. 
Most studies on prostate cancer (PrCa) have searched for inherited genetic variants that predispose men to overall PrCa risk. This study compares the prevalence of germline pathogenic genetic variants in men with aggressive and non-aggressive PrCa. The results confirm that germline gene panel testing allows identifying men who carry $B R C A 2$ pathogenic variants with increased risk of aggressive disease. Men with pathogenic variants in ATM were also at increased risk of aggressive disease. The findings contribute to the interpretation of the genetic variation identified in gene-panel tests and the evidence base for its clinical translation in the context of PrCa risk. 


\section{University Library}

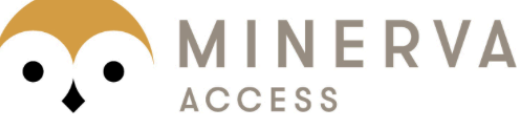

A gateway to Melbourne's research publications

Minerva Access is the Institutional Repository of The University of Melbourne

\section{Author/s:}

Nguyen-Dumont, T;MacInnis, RJ;Steen, JA;Theys, D;Tsimiklis, H;Hammet, F;Mahmoodi, M;Pope, BJ;Park, DJ;Mahmood, K;Severi, G;Bolton, D;Milne, RL;Giles, GG;Southey, MC

Title:

Rare germline genetic variants and risk of aggressive prostate cancer

\section{Date:}

2020-05-08

\section{Citation:}

Nguyen-Dumont, T., MacInnis, R. J., Steen, J. A., Theys, D., Tsimiklis, H., Hammet, F., Mahmoodi, M., Pope, B. J., Park, D. J., Mahmood, K., Severi, G., Bolton, D., Milne, R. L., Giles, G. G. \& Southey, M. C. (2020). Rare germline genetic variants and risk of aggressive prostate cancer. INTERNATIONAL JOURNAL OF CANCER, 147 (8), pp.2142-2149. https:// doi.org/10.1002/ijc.33024.

Persistent Link:

http://hdl.handle.net/11343/275725 